\title{
Bone Morphogenetic Proteins: An Overview
}

\author{
Anamika Sharma* and Himani Sharma \\ Department of Periodontology, Subharti Dental College and Hospital, Meerut India.
}

\begin{abstract}
For over years research has been carried out for finding the treatment procedures for the regeneration of a lost or injured part so that form and function of lost structures can be restored. This regenerative field holds the promise of engineering damaged tissues with the help of various growth factors including Bone Morphogenetic Proteins (BMPs), by stimulating the body's own repair mechanisms. BMPs constitute the largest subgroup of transforming growth factor beta superfamily. Till date over 30 members of this family has been identified. They are dimeric molecules and exhibit their effects using specific cell surface receptors. With the development of the techniques required for the isolation and cloning of these molecules, we are now able to understand their properties. They are powerful inductors of the osteogenic activity and have proliferative effects on various cellular types. This made us to use them in various therapeutic procedures including oral maxillofacial reconstruction, periodontal regeneration, enhancing osseointegration around dental implants and in various endodontic procedures. However, their effect is dosage and carrier dependent. Thus, the aim of this review is to help in understanding the structure, classification, signaling and role of BMPs in regeneration of bone and tissues.
\end{abstract}

\section{Keywords: Bone Morphogenetic Proteins, Regeneration, Growth Factors}

\section{Introduction}

The advancement in tissue engineering techniques has made it possible to develop various procedures utilizing the biological mediators like bone morphogenetic proteins (BMPs) for the regeneration of bone and tissues lost due to diseases. ${ }^{1,2}$

BMPs comprises of a group of potent, multi-functional growth factors, belonging to transforming growth factor beta (TGF- $\beta$ ) superfamily, which were discovered by Urist and coworkers ${ }^{3}$ in 1965.

They have been shown to play an important role in regulating the growth, differentiation and apoptosis of various cell types, including osteoblasts, chondroblasts, neural cells, and epithelial cells, depending on the cellular microenvironment and the interaction with other regulatory factors. ${ }^{4,5}$ Also when implanted into the bone matrix this protein component resulted in series of cellular events leading to mesenchymal cell infilteration, cartilage formation, vascularization, bone formation, and remodeling of the new bone along with proliferation of hematopoietic bone marrow elements. ${ }^{6}$

Hence, this review is an attempt to summarise the characteristics and various applications of Bone Morphogenetic Proteins.

\section{Classification of BMPs}

Till date only 20 different human BMPs have been discovered and classified into subfamilies, but including activin, inhibin, growth differentiating factors (GDFs) there are nearly 30 members in BMP family. ${ }^{7}$

BMPs are classified on the basis of their sequence similarities and functions into four subfamilies:-.

a. Ist group- BMP2 and BMP4 - (80\% homology)highly related molecules, differs mainly in amino terminal region, where BMP2 contains a heparinbinding domain.

b. IInd group- BMP3, BMP3B (GDF10) - also called as Osteogenin.

c. IIIrd group- BMP5, BMP6, BMP7, BMP8a, BMP8b - (78\% homology)

d. IVth group- GDF5, GDF6, GDF7-(cartilage-derived morphogenetic protein 1,2,3)

However, BMP1 is not considered as a member of TGF- $\beta$ superfamily, as it lacks the structure conserved in the TGF- $\beta$ superfamily. In some studies, it has been reported as a procollagen $\mathrm{C}$ - proteinase, processing procollagen to collagen. ${ }^{8,9}$

\section{Structure And Signaling Of BMPs}

BMPs are synthesized as precursor proteins having polypeptide chains ranging in size from 369-513 amino acids which are cleaved by pro-protein convertases and serine endoproteases to generate mature and active homodimers and heterodimers., , $^{30,11}$

These dimeric molecules, constitutes about 120 amino acids. It comprises of seven conserved cysteine residues. 
Out of these six forms a cysteine knot motif, linked with three intra-molecular disulfide bonds forming a critical core of the BMP monomer. ${ }^{10,12,13}$

BMP molecules exhibit their activity by binding to two types of specific cell surface receptors: Bone morphogenetic protein receptor, type 1 (BMPR 1) and Bone morphogenetic protein receptor, type 2 (BMPR 2). The BMP signaling cascade is initiated by binding to these cell surface receptors through- ${ }^{3}$

- Canonical pathways

- Non-Canonical pathways.

\section{Dosage And Carriers of BMP-}

The estimated amount of BMP per kilogram pulverized bone is $0.002 \mathrm{mg} .{ }^{14}$ The amount of BMP required to induce bone bridging in osseous defects depends upon- the state of organism in the evolutionary scale, anatomic location of the site of application and the type of defect. ${ }^{15,16}$

BMP is water soluble, and diffuses very easily in body fluids. For the effectiveness BMPs require a competent carrier in order to be contained. ${ }^{10,15}$

These carriers can be broadly classified into - naturally occurring polymeric substances, inorganic salts, synthetic polymers and composites of synthetic and naturally occurring polymers and titanium. About 15-55\% of increased retention was seen when BMPs were combined with gelatin foam or collagen. ${ }^{17}$

\section{Regenerative Potential of BMPs-}

Bowers et al, ${ }^{18}$ described the first successful use of BMP for periodontal regeneration. BMPs, demonstrates pleotrophic effects on the stimulation of several key events required for tissue regeneration including DNA synthesis, chemotaxis, differentiation, and matrix synthesis. ${ }^{19,20}$

Several tests have been conducted, demonstrating the increased regeneration of alveolar bone, periodontal ligament(PDL) and cementum in bone defects, bone healing, acceleration osteointegration, oral and maxillofacial reconstruction, bone pathology sequel repair, distraction osteogenesis as well as, in endodontic procedures. . $21,22,23,24,25$ Treatment of endosseous implants with bovine BMP and rhBMP-2 caused the stimulation of agreater amount of bone deposition and bone-to-implant contact, which was more significant after 4 and 12 weeks of healing. ${ }^{26,27,28}$

The anabolic effect of BMPs on periodontal tissues is through stimulation of osteoblastic differentiation in human PDL cells and by stimulation of alkaline phosphatase activity in periosteal cells thus, enhancing the regeneration of new connective tissue attachment and bone in both root submerged and non-submerged environment. ${ }^{13,23}$

Thus, concluding that BMPs offer promise as an attractive candidate for treating severe periodontal lesions with significant potential for stimulating periodontal regeneration. ${ }^{23}$

\section{Conclusion}

Several studies have highlighted that BMPs provide a framework for the regeneration of the various tissue components of the periodontium and, in addition, may play important physiological roles in repair, regeneration and remodeling. However, despite a great deal of research effort, the ideal treatment modality using BMPs has yet to be established and further basic research is required to elucidate the detailed mechanism of BMP receptor activation and signal transduction to the cell nucleus and the their clinical applications.

\section{References}

1. Newman MG, Takei H, Klokkevold PR, Carranza FA. Carranza's Clinical Periodontology 11th edition. Elsevier health sciences; 2015

2. Kao RT, Murakami S, Beirne. The use of biologic mediators and tissue engineering in dentistry. Periodontol. 2000 2009;50:127-53.

3. Richard NW, Jordan, Zhongliang W, Youlin D, Min Q, Michael $\mathrm{P}$ et al. Bone Morphogenetic Protein (BMP) Signaling in Development and Human Diseases. Genes \& Diseases. 2014;1(1):87-105.

4. Kingsley DM. The TGF-b superfamily: New members, new receptors, and New genetic tests of function in different organisms. Genes Dev. 1994;8:133-46.

5. Wang EA. Bone morphogenetic proteins (BMPs): Therapeutic Potential in healing bony defects. Trends Biotechnol. 1993;11:379-83.

6. Reddi AH. Cell biology and biochemistry of endochondral bone Development. Coll Relate Res. 1981;1:209-26.

7. Reddi AH. Bone Morphogenetic Proteins: An unconventional approach to isolation of first mammalian morphogens. Cytokine \& Growth Factor reviews. 1997;6:11-20.

8. Karuppanan PS, Elavarasu S, Jayaprakash SG. The application of bone morphogenetic proteins to periodontal and peri-implant tissue regeneration: a literature review. J pharm bioallied sci. 2012;4:427-30.

9. Sakau T. Bone Morphogenetic Proteins: From Basic Studies To Clinical Approaches. Bone. 1998;22(6):591-603.

10. Lee MB. Bone morphogenetic proteins: background and implications for oral reconstruction.J ClinPeriodondol. 1997;24:355-365.

11. Kawabata M, Imamura T, Miyazono K. Signal transduction by bone morphogenetic proteins. Cytokine Growth Factor Rev. 1998;9(1):49-6. 
12. Griffith DL, Keck PC, Sampath TK, Rueger DC, Carlson WD. Three-dimensional structure of recombinant human osteogenic protein 1: structural paradigm for the transforming growth factor beta superfamily. ProcNatlAcadSci U S A. 1996;93:878-883.

13. Ripamonti U, Reddi AH. Periodontal regeneration: potential role of bone morphogenetic proteins .Journal of Periodontal Research. 1994;29(4):225-235.

14. Nelsen SM, Christian JL. Site-specific cleavage of BMP4 by furin, PC6, and PC7.J BiolChem 2009;284(40):27157-66.

15. Setti SR. Bone morphogenetic proteins: basic concepts. Neurosurg Focus. 2002;13(6):1-6.

16. Setti SR. Bone morphogenetic proteins: basic concepts. Neurosurg Focus. 2002;13(6):1-6.

17. Ziyad S, Haidar ZS, Hamdy RC, Tabrizian M. Delivery of recombinant bone morphogenetic proteins for bone regeneration and repair. Part A: Current challenges in BMP delivery. BiotechnolLett. 2009;31:1817-1824.

18. Vukicevic S, Sampath KT, editors. Bone Morphogenetic Proteins.In:Regeneration of Bone and Beyond.Elseveir; 2004. pg45-72.

19. Bowers G, Felton F, Middleton C, Glynn D, Sharp S, Mellonig $\mathrm{J}$, et al. Histologic comparison of regeneration in human intrabony defects when osteogenin is combined with demineralized freeze-dried bone allograft and with purified bovine collagen. J Periodontol. 1991;62:690-702.

20. Sigurdsson TJ, Lee MB, Kubota K, Turek TJ, Wozney JM, Wikesjo U. Periodontal repair in dogs: Recombinant human bone morphogenetic protein-2 significantly enhances periodontal regeneration. Journal of periodontology. 1995;66:J31-I38.

21. Saito A, Saito E, Handa R, Honma Y, Kawanami M. Influence of residual bone on recombinant human bone morphogenetic protein- 2-induced periodontal regeneration in experimental periodontitis in dogs. J Periodontol. 2009;80:961-968.

22. Bashutski JD, Wang HL. Biologic agents to promote periodontal regeneration and bone augmentation. Clinical Advances in Periodontics. 2011;1(2):80-87.

23. Díaz-Sánchez RM, Yáñez-Vico RM, Fernández-Olavarría A, Mosquera-Pérez R, Iglesias-Linares A, Torres-Lagares D. Current approaches of bone morphogenetic proteins in dentistry. J Oral Implantol. 2013;41:337-42.

24. Weng D, Poehling S, Pippig S, Bell M, Richter EJ, Zuhr O et al. The effects of recombinant human growth/differentiation factor-5 (rhGDF-5) on bone regeneration around titanium dental implants in barrier membrane-protected defects: a pilot study in the mandible of beagle dogs. Int J Oral Maxillofac Implants. 2009;24:31-7.

25. Giannobile WV, Somerman MJ. Growth and amelogeninlike factors in periodontal wound healing. A systematic review. Ann Periodontol. 2003;8:193-204.

26. Hanisch O, Tatakis DN, Rohrer MD, Wöhrle PS, Wozney JM, Wikesjö UM. Bone formation and osseointegration stimulated by rhBMP-2 following subantral augmentation procedures in nonhuman primates. Int $\mathrm{J}$ Oral Maxillofac Implants. 1997; 12:785-92.

27. Cochran DL, Schenk R, Buser D, Wozney JM, Jones AA. Recombinant human bone morphogenetic protein-2 stimulation of bone formation around endosseous dental implants. J Periodontol. 1999;70:139-50.

28. Cochran DL, Jones AA, Lilly LC, Fiorellini JP, Howell $\mathrm{H}$. Evaluation of recombinant human bone morphogenetic protein-2 in oral applications including the use of endosseous implants: 3-year results of a pilot study in humans. J Periodontol. 2000;71:1241-57.

*Corresponding author:

Dr. Anamika Sharma, Professor \& Head, Department of Periodontology, Subharti Dental College \& Hospital, Meerut., INDIA

Phone: +9109219600994

Email: prof_anamika@hotmail.com

Financial or other Competing Interests: None.

Date of Submission : 09.02.2017

Date of Acceptance : 14.04.2017

Date of Publication : 30.04.2017 